\title{
Factors Determining Use of Biological Disease Control Measures by the Avocado Industry in South Africa
}

\author{
M van Eeden*, L Korsten \\ Department of Microbiology and Plant Pathology, University of Pretoria, Pretoria 0002, South Africa
}

*Corresponding author:

Tel: +2782 461 5998; Fax: +2786 513 8251; E-mail address: madelve@lantic.net.

\begin{abstract}
Farmers in the northern avocado cultivation areas of South Africa were interviewed concerning their experience and perceptions of biological control. Factors affecting their decision to use biological control programmes as a disease control strategy, was also investigated. Results indicate that educational level, age and land owner status reflect the farmer's decision making ability and the level of commitment to adopt the new technology. Generations of family farming and farm management systems that have adopted food safety management systems also had an influence on their willingness to explore biological control. Although most farmers were aware of biological control, most could not define it. Farmers did not blame biological control for the previous poor results, but rather on environmental factors and a lack of perseverance on their side with the use of the product. Land reform aims to redistribute 30 percent of the country's agricultural land from white commercial farmers to previously disadvantaged communities by 2014. Farmers on farms with completed or invalid land claims were more willing to utilise biological control than growers without claims or with land claims that are pending. Companies distributing and selling biocontrol products indicated that the lack of technical knowledge by sales personnel is one of the main problems experienced with marketing biocontrol products. Manufacturing companies also experienced difficulty with the registration of new products in South Africa.
\end{abstract}

Key words: Biological control, Avocado, Adaptation, South Africa 


\section{Introduction}

Safer products with reduced environmental impact and alternative modes of action contribute to the fact that biological control offers a powerful alternative to chemical disease control (Harman, 1998; Fravel, 2005; Bailey et al., 2010). The Global Industry Analysts, Inc. (GIA) published a comprehensive review "Biopesticides: A Global Strategic Business Report" regarding biopesticide market trends for the United States, Canada, Europe, Asia-Pacific (including Japan), Latin America and the rest of the world (2007 to 2015) (http://www.strategyr.com/Biopesticides_Market_Report.asp). GIA estimated that biopesticides represented about 3\% (\$750 million) of the global pesticides market in 2008, $\$ 1$ billion by

2010 and is forecast to reach US $\$ 2.8$ billion by the year 2015 (http://www.biopesticideindustryalliance.org). Yet, although the number of biocontrol products commercially sold is increasing globally, major economic success stories are rare (Irtwange, 2006). Obstacles facing successful adaptation of biocontrol strategies include a limitation in the number of biological control products available and high cost associated with these products making it often more expensive than existing chemical products (Jatsum et al., Harman, 1998; Fravel, 2005). The effect of environmental factors on biological control mechanisms can result in unreliability and unpredictability of this approach (Jatsum et al., 1988). Lack of basic knowledge on the use of biocontrol in general causes conventional chemical control programs still to be preferred in commercial agriculture (Harman, 1998).

Avocado (Persea Americana Mill.) are susceptible to various fruit diseases, including Black spot (Pseudocercospora purpurea (Cooke) Deighton (Darvas et al., 1987), stem-end rot (Phomopsis perseae Zerova, Dothiorella aromatica (Sacc.) and anthracnose (Colletotrichum gloeosporioides (Penz.) Penz. \& Sacc.) in South Africa (Korsten et al., 1994). Currently, the pre-harvest disease control program for these pathogens involves sprays with copper-based fungicides (Towsen et al., 1995). According to Korsten et al. (1997), copper oxychloride proved to be ineffective against Cercospora spot of avocado during one field trail (Korsten et al., 1997). This might be attributed to the wash-off effect of copper 
during times of rain that result in poor fruit coverage and therefore achieving lower levels of control (Everett et al., 2005). This, together with concerns regarding copper build up in soils and unwanted residues on fruit, raised the interest in alternative disease control options favouring more environmental friendly approaches such as using biological control.

Avogreen $^{\circledR}$ (Bacillus subtilis) is registered as the only pre-harvest biological control agent against avocado fruit diseases in South Africa. Although the product has been on the market since 1996, is accepted in organic production systems and is fully GlobalGap compliant, few growers have used this product (Correspondence, Prof. Steyn, Stimuplant, South Africa).

Land reform in South Africa aims to distribute 30 percent of the country's agricultural land from commercial white farmers by 2014 (www.etu.org.za). In this process, farmers' often refuse to sell their land to make way for restitution (Fraser 2008). New emerging farmers, on the other hand, battle the cost and lack the infrastructure required to establish new farming practices (Groenewalt, 2003). Land reform must therefore surely have an effect on management decisions made by farmers in the South African avocado industry. This paper reports on investigation of political and social factors affecting adaptation of biological control in the avocado industry, with special reference to Avogreen ${ }^{\circledR}$. The study will help to identify misconceptions and gaps in farmer's knowledge regarding biological control and challenges faced by biopesticide companies.

\section{Materials and methods}

This study was conducted during the 2008 growing season in the northern avocado production areas of South Africa. Two surveys were conducted, one targeting the farming community and the other the suppliers of biological control products. In the farming community survey, questions were divided into three main sections. Section one addressed farmers' socio-economic background, including farmer age, sex and education level. This section also covered type of farm certification system employed and type 
of research performed on the farm, if any. Section two focused on biological control and investigated farmer history of biocontrol usage, farmer awareness of biological control systems, knowledge on its definition and willingness to adopt biological control practices. The third section contained questions pertaining to the impact of land reform on farmer decision making and willingness to adopt biological control practices.

The second survey involved interviews with agricultural biopesticide distribution companies in general in order to get an idea of difficulties faced when producing, distributing and establishing biological control products in the South African avocado industry. Questions directed to them included, number of employees, age of companies, nature of research performed and problems encountered during the production and distribution of biological control products. Eleven companies were interviewed by telephone (summary of interview in Table 4). The information about these companies was obtained from the National Department of Agriculture and the Association of Veterinary and Crop Associations of South Africa (AVCASA). Companies in their database are listed on Croplife South Africa, an association representing $90 \%$ of crop protection product importers, manufacturers and suppliers in South Africa. It has 64 companies as members (www.croplife.co.za).

\subsection{Data analysis}

Cross-tabulation was used to summarize the most important categories such as age, educational level, land owner status, etc. with regard to willingness to use biological control products and the effect of land claims on farmer decision making. The Chi-square test was performed on percentage farmers willing to use biocontrol as influenced by land owner status, food safety certification, generation of farming and educational level. The test was also performed on percentage farmers willing to perform research on their farms as influenced by educational level. When a sample of individuals can be classified according to two attributes the result is a two-way frequency table known as a row by column $(\mathrm{r} \mathrm{x} \mathrm{c})$ contingency table (Snedcor and Cochran, 1980). This classification system is used to determine if the distributions 
are the same for each variable or if it differs. The Chi-square $\mathrm{r} x \mathrm{c}$ test is therefore useful to determine if there are significant differences between the two independent attributes. This test has certain limitations (Siegel 1956), namely, no category may have an expected frequency of less than five.

\section{Results and discussion}

\section{The Survey}

This is the first survey on the effect of sociological influences and land claim status on the successful adaptation of biological control that has been conducted in South Africa. The only other study that could be found for South Africa that to some extend is comparable with this survey was published by van der Waals et al. (2003), who surveyed control practices and grower perceptions of early blight in South Africa (van der Waals et al., 2003). On an international level, Moser et al. (2008), found that farmers attitudes towards the use of biocontrol agents in integrated pest management (IPM) in strawberry production in three countries (Italy, Israel and Germany) varied from region to region and was influenced by the amount of time and cost required to monitor the antagonist, the lack of pest control and the influence of environmental factors on antagonist performance. The farmers interviewed were more aware of the positive aspects of biocontrol agents than the negative ones, most probably due to media coverage (Moser et al., 2008).

\section{Farmer and farm characteristics}

In the current study, a total of 76 (Levubu - 11, Kiepersol - 8, Tzaneen - 21, Nelspruit - 4, Hoedspruit - 5 and Vhembe -23) farmers out of 143 completed the questionnaires (Table 1). In total, 420 avocado farmers operate in South Africa and the survey was therefore distributed to $34 \%$ of the growers of which a total of $17.9 \%$ completed the questionnaires. The areas covered represent the major avocado growing areas in South Africa. According to the South African Subtropical Growers' Association (SUBTROP), avocado trees actively cultivated in South Africa are distributed between the Limpopo Province (53 \%), Mpumalanga (37\%), Natal (9\%) with the remaining scattered through the other provinces 
(Correspondence, SUBTROP, Census data 2009). Because of the difficulty to reach farmers in Natal, they were not included in this study and the survey focused mainly on the two major regions. Farmers cultivated a wide range of subtropical fruit, including avocado (29\%), macadamia (10\%), mango (31 $\%)$, pecan (4\%), litchi (6\%), guava (6\%), citrus (3\%), granadilla (1\%), banana $(6 \%)$ and even sugarcane (4\%), in various combinations.

Table 1 Age and sex of farmers interviewed as well as location of their farms and destination of fruit cultivated

\begin{tabular}{llll}
\hline Question & Aspect & Number & Percentage \\
\hline Area distribution & Levubu & 15 & 20 \\
& Kiepersol & 8 & 11 \\
& Tzaneen & 21 & 28 \\
& Nelspruit & 4 & 5 \\
& Hoedspruit & 5 & 7 \\
& Vhembe & 23 & 29 \\
& Total = 6 production regions & 76 & $100 \%$ \\
\hline Target market & Export market & 31 & 41 \\
& Local market & 45 & 59 \\
\hline Local market destination & Market & 18 & 40 \\
& Vendors & 27 & 60 \\
\hline Sex & Male & 71 & 93 \\
& Female & 5 & 7 \\
\hline Age distribution & Less than 20 years of age & 0 & 0 \\
& Between 20 and 30 & 7 & 9 \\
& Between 31 and 40 & 22 & 29 \\
& Between 41 and 50 & 15 & 20 \\
& Between 51 and 60 & 24 & 31 \\
& More than 60 years of age & 8 & 11 \\
& Total = 6 age ranges & 76 & $100 \%$ \\
\hline
\end{tabular}

Farmers interviewed were mostly male (93\%) (Table 1). Out of the sample group, $41 \%$ of farmers indicated that their fruit was mainly exported and $59 \%$ indicated that the fruit was designated for domestic markets. Of the group that focuses mainly on South African markets, $40 \%$ sends the fruit to fresh produce markets (mainly Tswane, Johannesburg, Cape Town and Durban) and $60 \%$ sells through vendors (Table 1). International best practices certification on farms included organic certification (2.6 \%), South African Good Agricultural Practices (SAGAP) (www.daff.gov.za) (2.6 \%), GLOBALGAP (www.globalgap.org) (44.73\%) and Tesco Natures Choice (www.tesco.com) (7.89\%). Pack house 
facilities on farms were Hazard Analysis Critical Control Point (HACCP) (14.4\%) and BRC (British Retail Consortium) (www.brcglobalstandards.com) (5.26\%) certified. These standards promote the use of products that is safer for humans and the environment and biological control products therefore fits well into this framework. Food safety certification was evident on farms willing to explore biological control in this study (Table 2). Farmers in process of obtaining certification or without any kind of certification were mostly negative towards the idea of biological control.

Table 2 Effect of land owner status, farmer age and food safety certification on willingness to use biological control $\left(\chi^{2} d f=1\right)$

\begin{tabular}{|c|c|c|c|c|}
\hline Question & Aspect & Willing to use & Unwilling to use & Total \\
\hline Land owner & Owner & $29(93.55 \%)$ & $2(6.45 \%)$ & 31 \\
\hline \multirow{5}{*}{ Status } & Manager & $16(100 \%)$ & $0(0 \%)$ & 16 \\
\hline & Community representative & $1(100 \%)$ & $0(0 \%)$ & 1 \\
\hline & Agricultural advisor & $1(100 \%)$ & $0(0 \%)$ & 1 \\
\hline & $\chi^{2}$ & 1.08 & & \\
\hline & Probability & 0.299 & & \\
\hline \multirow{6}{*}{$\begin{array}{l}\text { Generation } \\
\text { farming }\end{array}$} & First farming generation & $26(50.98 \%)$ & $25(49.02 \%)$ & 51 \\
\hline & Second farming generation & $9(81.82 \%)$ & $2(18.18 \%)$ & 11 \\
\hline & Third farming generation & $10(83.33 \%)$ & $2(16.67 \%)$ & 12 \\
\hline & Fourth farming generation & $2(100 \%)$ & $0(0 \%)$ & 2 \\
\hline & $\chi^{2}$ & 7.79 & & \\
\hline & Probability & 0.02 & & \\
\hline \multirow[t]{4}{*}{ Certification } & Certification & $57(91.94 \%)$ & $5(8.06 \%)$ & 62 \\
\hline & No certification & $14(36.84 \%)$ & $24(63.16 \%)$ & 38 \\
\hline & $\chi^{2}$ & 34.73 & & \\
\hline & Probability & $<0.001$ & & \\
\hline
\end{tabular}

$\%$ Export per date followed by a different letter was significantly different at the $0.05 \%$ level;

$\chi^{2}=$ Tabled Chi-Squared value; $\left(\chi^{2} d f\right)=$ D.F.

Owners of agricultural land were slightly less willing to utilise biological control products than farm managers or community representatives (for new emerging farmers) (Table 2). Willingness to adopt biocontrol increased with each farming generation of a specific family that is farming on the same land (Table 2). 
Studies on farming strategies, has widely accepted farmer age as a good indicator of the influence of life-cycle factors on decision making (Acka et al., 2006; Burton, 2006; Agwu, et al., 2008). As such, farmer age has become an important aspect of many quantitative studies of agricultural change (Acka et al., 2006; Burton, 2006; Agwu, et al., 2008; Bageri, 2010; Mzoughi, 2011; Ying and Min, 2011). Age distribution for the current study is indicated in Table 1. Age had a definite influence on the farmer's ability to make decisions, and to use or explore biological control practices (Fig.1). Farmers between 20 and 40 years of age were the most open for a biological disease control approach. Reduction in the willingness of farmers to explore biological control was also associated with an increase in age above 40, most probably reflecting older farmers' confidence in more traditional methods of farming and disease control. Similar results was found by Lobley et al. (2009), who found that a distinctive profile exist for organic farmers in England and that people who operate organic farms are typically younger and more highly educated (Lobley, et al., 2009).

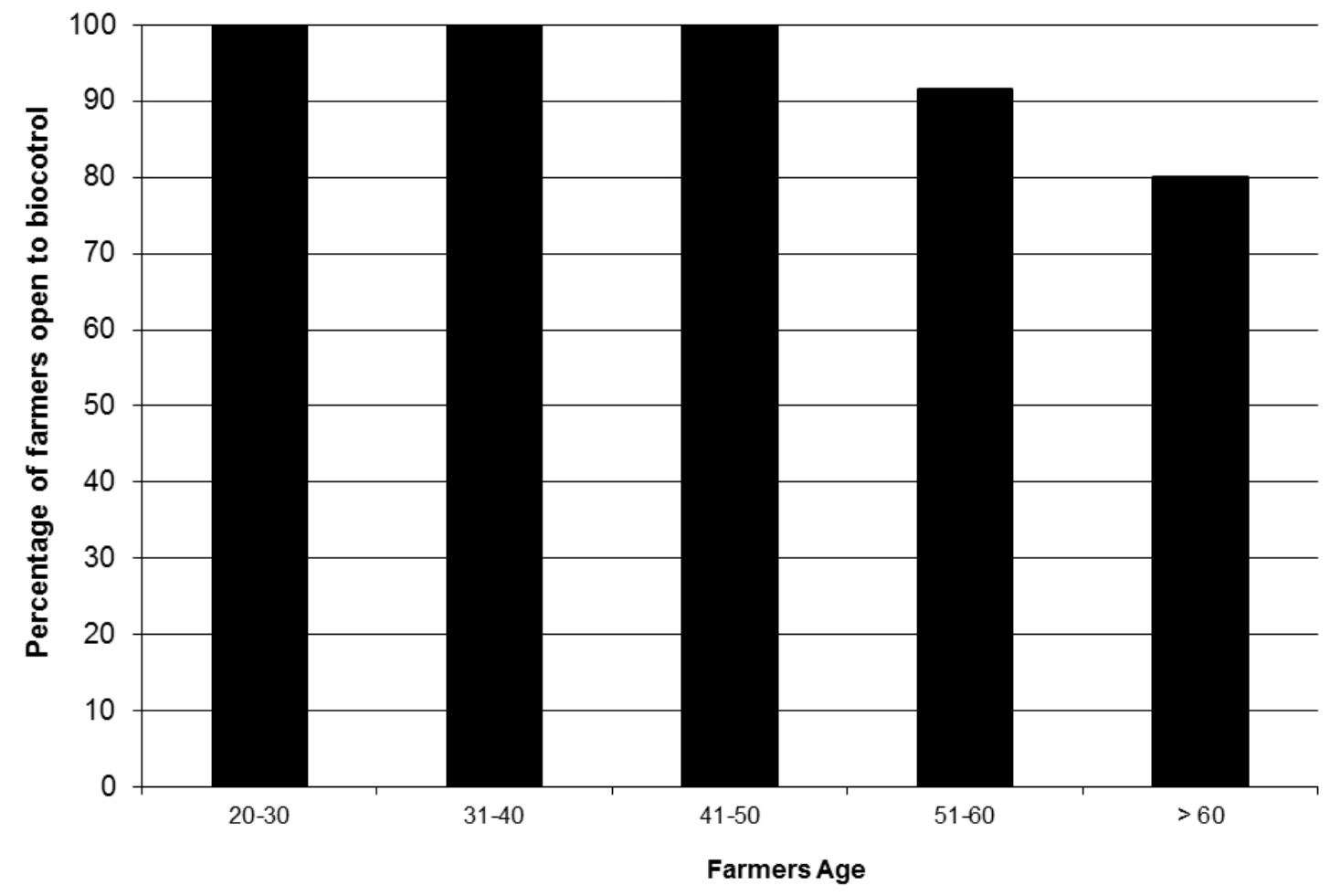

Fig.1 Effect of farmer age on willingness to use biological disease control (Number $=76$ in 5 age ranges) 


\section{Farmers experience with biocontrol}

Growers from Nelspruit, Levubu and Hoedspruit have the most experience with biological control practices (Fig.2), followed by Kiepersol and Tzaneen. New emerging farmers from the Vhembe area

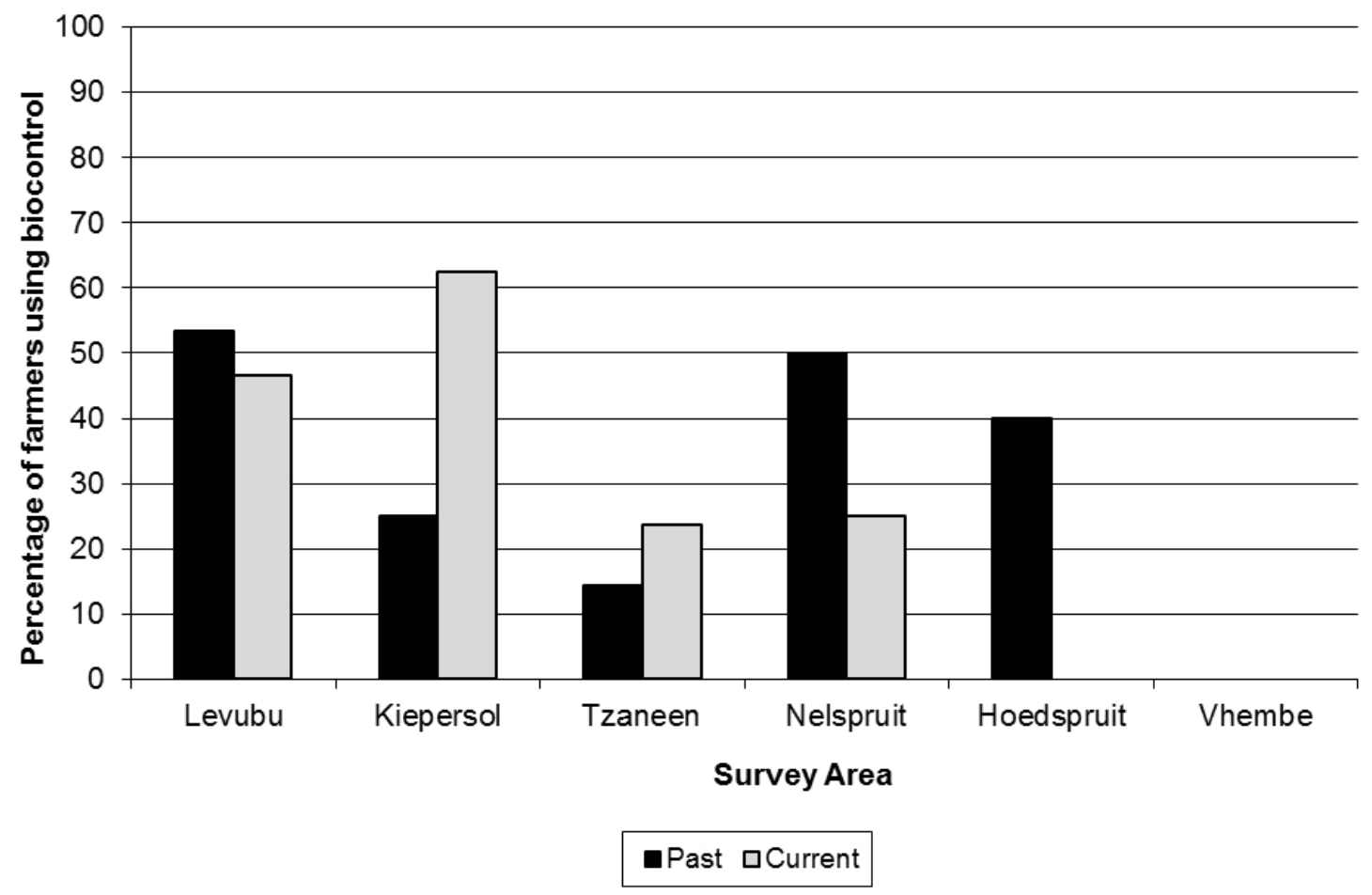

Fig.2 Percentage farmers (participating in survey) that are currently or have ever in the past used any kind of biological control product in each respective area ( Number $=76$ of farmers in six production regions).

(Thohoyandou) indicated that they've never been involved with any kind of biological control programs. Several farmers from Levubu, Kiepersol, Nelspruit and Tzaneen are currently using biological control products (Fig.2). This most probably reflects the activity of the South African Growers' Association and qualified field technicians in these areas where they actively work with farmers to identify and address agricultural problems. This is usually supported by active farmer study groups where farmers are trained and research information are channeled back to farmers (Correspondence, South African Avocado Growers' Association, Tzaneen, South Africa, 20 April 2010). Forty percent of the farmers with experience in using biological control products ( $24 \%$ of total) indicated that they obtained good disease control with biological programs. Insufficient control was achieved by $36 \%$ of farmers and 11 
$\%$ of grower's experienced no control when applying biocontrol products. Inconsistent results in biocontrol were reported by $11 \%$ of the farmers. Two percent of the farmers achieved good control, but indicated that biological control was too expensive to utilize. A single chemical fungicide application (applicable on an $8 \times 8 \mathrm{~m}$ tree spacing orchard at an application volume of $60 \mathrm{~L} /$ tree) ranges from $\mathrm{R} 1$ 419.00 (\$ 164.05) / ha (hectares) for Copstar ${ }^{\circledR}$ (approximately four applications per season and only during conditions of low disease pressure), R 1600.34 (\$185.01)/ ha for Coprox Super ${ }^{\circledR}$ (approximately four applications per season) to R 801.44 (\$92.65) / ha for $\mathrm{Knowin}^{\circledR}$ (up to two applications at the start of the growing season) and as low as $\mathrm{R} 461.64(\$ 53.64) /$ ha for Benomyl ${ }^{\circledR}$ (up to two applications at the start of the growing season) (Prices confirmed by Laeveld Agrochem, Louis Trichardt, South Africa on 16 April 2010). Application of Avogreen ${ }^{\circledR}$ will cost R 1965.60 (\$227.24) / ha (four applications per season recommended).

Drawbacks of biological control as highlighted by farmers included inconsistent results when using these products $(17 \%)$, unavailability of information on biological control $(16 \%)$, unavailability of biological control products (12\%), cost of products (8\%), and difficulty of use $(2 \%)$ and application (1

$\%$. Interestingly, none of the farmers indicated that they are of an opinion that biological control products does not work. In contrast, reduced environmental risk (22\%), production of safer crops (19 $\%)$, reduced health risk (14\%) and an economic benefit associated with the use of these products (7\%) was highlighted as advantages. Although $41 \%$ of the farmers were of the opinion that biological control products were available for their industry, over $50 \%$ were of the opinion that there is limited availability, or that it is unavailable.

\section{Farmer education level and understanding of biocontrol}

Growers mostly didn't understand the concept of biological control, and only $26 \%$ correctly defined biological control as basically the use of natural enemies to reduce the damage caused by a pest population. Incorrect definitions given by farmers included the use of natural products $(17 \%)$ and the use of organic products $(14 \%)$ in agriculture. A total of $43 \%$ of the farmers could not define 
biocontrol. Farmers, who correctly defined biological control, obtained their biocontrol knowledge from growers associations (26\%), literature (22\%) and the media (13\%). Farmers did however mostly indicate that they are willing to use biological control products on a large $(26 \%)$ or small $(33 \%)$ scale, and only $3 \%$ indicated that they are unwilling to prompt for this approach. Uncertainty was indicated by $38 \%$ of growers.

It is therefore possible that more knowledge regarding biological control may result in a greater acceptance towards the use of biological control practices. Education and access to information sources is a key element in understanding and acceptance of alternative disease control programs (Andrews, et al., 1992; Bagheri, 2010; Mzoughi, 2011; Ying and Min; 2011). Success of biological control can be enhanced through farmer education, especially if the speed of biological control acceptance is slow (Jatsum et al., 1988). The education process may simply involve participation of the farmer in the entire biological control process. In turn, this involvement can help to focus research to identify factors that prevent successful biological control. Understanding of biological control and the benefits surrounding these programs could also result in a greater support from farmers on a financial, logistical and intellectual level (Norton, 1976; Andrews et al., 1992; Valentin, 2002).

Farmers education was further reflected in the amount of research conducted on farms. Farmers in all growing areas indicated that they allow researchers to do experimental trials on disease control on their farms (51\% of farmers). However the percentage research was very low in the Vhembe district where only one farmer indicated that experimental trials is sometimes performed on his farm. There was a strong correlation between the level of farmer education and research done on the farm, as well as the willingness to perform biological control trials. Farmers with a higher education level were more open for a biological pest control approach (Fig.3) and allowed more research to be done on their farm. All farmers without schooling are from the new emerging farmers group. Research parties included agricultural companies as listed in Table 4 (48\%), personal research by farmers (33\%), universities (including university of Pretoria) (17\%), and research performed by the Institute for Tropical and 
Subtropical Crops (2\%) (Agricultural Research Council, Nelspruit, South Africa). The later organisation has its own research farms available for field trials. Personal research by farmers did not necessarily

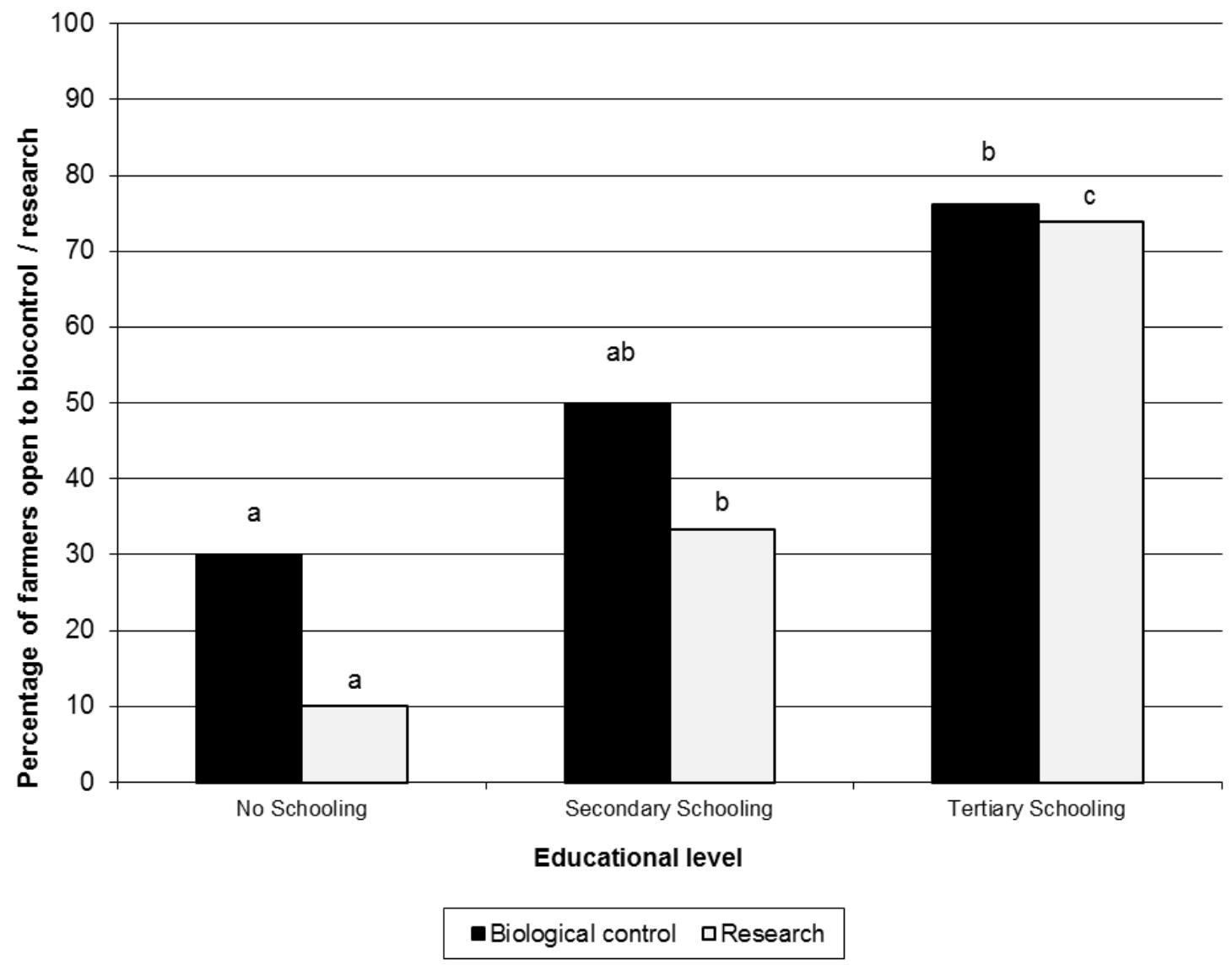

Fig.3 Effect of educational level on the receptiveness of farmers to utilize biological control and to perform research on their farms $\left(\chi^{2} d f=2\right)$ Probability $<\mathbf{0 . 0 0 0 1}$ (Number $=76$ of farmers in three educational levels).

include statistical trails, but rather comparison of different products and serves as indication of their openness towards new technology.

\section{Farmer attitude towards biocontrol and the use of Avogreen ${ }^{\circledR}$}

The large percentage of growers $(38 \%)$ felt that they did not persevere long enough in the use of the biocontrol product to obtain what they consider as positive results. This is despite the fact that the 
biocontrol agent has previously been shown to be effective to control avocado fruit diseases (Korsten et al., 1997). Results indicated that respondents generally demonstrated a positive attitude towards biological control and believed in the long term effectiveness of this approach as a disease control method. Although most respondents did not utilise biological control before, they were more than willing to opt for this approach. Farmers also strongly believed that poor results obtained this far, did not reflect the inability of biocontrol products to control disease.

Although Avogreen ${ }^{\mathbb{B}}$ has since been registered as a biological control product for avocado disease control in the South African market, grower's acceptance has been low. The product has previously been used by $13 \%$ of the farmers interviewed. These farmers indicated that they either experienced poor commercial control $(90 \%)$ or inconsistent results $(10 \%)$ with the use of this product. According to them, possible reasons could be due to poor formulated product performance, poor coverage of the tree by the antagonist $(31 \%)$ due to inadequate spray applications or environmental factors $(19 \%)$. Six percent were of the opinion that it is a poor product and six percent couldn't determine if it worked or not. It is therefore necessary to address perceptions and possible factors affecting product inconsistency under fluctuating environmental conditions or poor technical support in order to enhance success of the program.

\section{Effect of land claim status}

Over $40 \%$ of the farmers indicated that they have land claims on their farms that is either pending or that they are contesting in court. The farms that had no claims represented $43 \%$, while $3 \%$ was settled and $7 \%$ was invalid. Farmers on farms with settled claims, invalid claims or that is in the process of contesting claims were very positive towards the idea of using biological control as disease control mechanism (Fig.4). It is possible that these farmers are more experimental and willing to investigate more options because they have a more long term future on the farm. Negativity towards biological control was evident in farmers' attitudes with pending land claims. It was interesting to note that growers on farms without any claims were mostly unwilling to utilise biocontrol strategies. Majority of 
these farmers are new emerging farmers without previous experience of biological control. Their unwillingness to explore biological control is once again reflecting the lack of education (Fig.3).

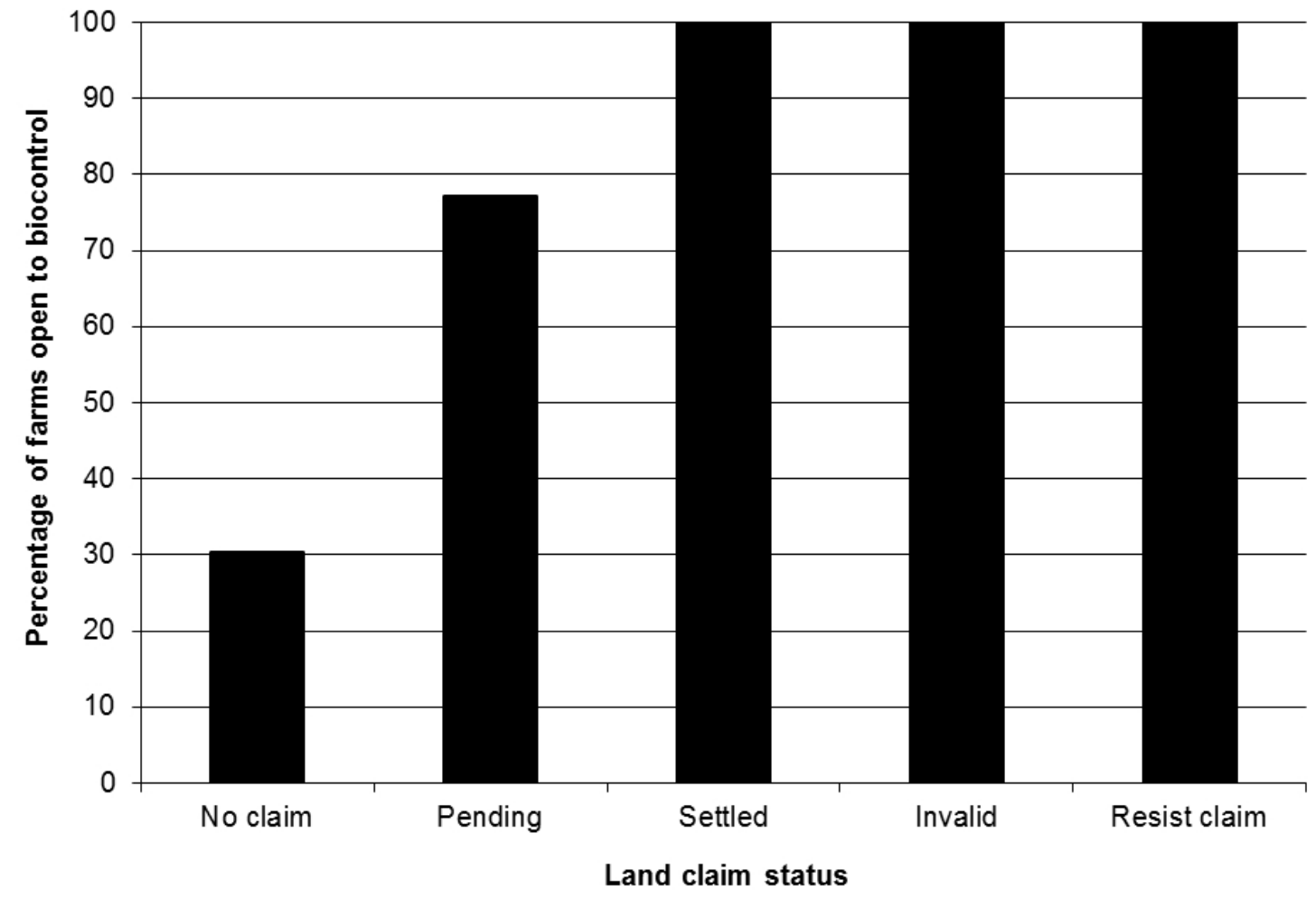

Fig.4 Effect of land claim status on farmers' willingness to utilize biological control (Number $=76$ farmers).

Table 3 Problems facing new upcoming farmers

\begin{tabular}{lll}
\hline Aspect & Number & $\mathbf{\%}$ \\
\hline Irrigation & 12 & 25 \\
Fence & 1 & 2 \\
Price of products & 7 & 15 \\
Draught & 3 & 6 \\
Plant disease & 4 & 8 \\
Theft & 3 & 6 \\
Electricity & 1 & 2 \\
Lack of funds & 17 & 36 \\
Total = 8 problems facing farmers & 48 & $100 \%$ \\
\hline
\end{tabular}

Problems facing new upcoming farmers include lack of funds for farming practices (36\%), lack of irrigation systems (25\%), price of agricultural input products $(15 \%)$, plant diseases $(8 \%)$, theft (6\%) and a lack of electricity ( $2 \%)$ and fencing ( $2 \%$ ) (Table 3$)$. Other factors indicated by farmers that may 
have a potential effect on their decision to use biological control is availability of the product, cost and ease of application of the product and back up assistance by the manufacturer/distributor/agent.

\section{Registration and marketing of biocontrol products}

A total of 15 companies that were interviewed sold and / or produced biological, organic, partial organic and in certain cases chemical products. Only four of the companies indicated that they did not have international alliances (Table 4). Three of the companies were less than 10 years old, seven between 10 and 20 years and five companies were older than 20 years (Table 4). According to Croplife (www.croplife.co.za), there are currently six companies with registered products for biocontrol of plant diseases in South Africa.

The companies interviewed represent large scale companies with much experience in agriculture. Most companies indicated that they performed research mostly in-house, although universities and contractors were also involved. In-house research in all companies interviewed was performed by staff members with tertiary qualifications. Companies indicated that their main problem with establishing biological control products in the agricultural market includes:

- A large number of factors that can influence the success of biological control products (e.g. fluctuating environmental conditions);

- Perceived previous success and consistency experienced with chemical disease control products;

- Perceived lower success rate obtained with biocontrol, compared to chemical disease control programs

The Department of Agriculture, Forestry and Fisheries (DAFF) published agricultural remedies that are registered by the Registrar of the Pesticides, Farm Feeds, Agricultural Remedies and Stock Remedies Act, Act No. 36 of 1974 in South Africa on CropLife, a comprehensive database available on the internet (www.croplife.co.za). This database contains information useful for registration holders, 
farmers, consultants, agricultural chemical distributors, regulatory authorities, students, environmental health practitioners and others who may from time to time require basic information about agricultural remedies in South Africa. From the 3201 fungicides listed only ten are biological control products

Table 5 Biological control products registered in South Africa as indicated in latest product registration list published (2001) (www.croplife.co.za). Reg No. = registration number

\begin{tabular}{|c|c|c|c|c|c|c|}
\hline $\begin{array}{l}\text { Reg } \\
\text { No. }\end{array}$ & Company name & $\begin{array}{l}\text { Product } \\
\text { name }\end{array}$ & Active/s & Concentration & Crop & Problem \\
\hline 6533 & RE at UP & Avogreen & $\begin{array}{l}\text { Bacillus subtilis } \\
\text { isolate B246 }\end{array}$ & $\begin{array}{l}1 \times 10(9) \\
\text { spores/ml }\end{array}$ & Avocadoes & Fruit spot \\
\hline 6685 & RE at UP & $\begin{array}{l}\text { Avogreen } \\
\text { WP }\end{array}$ & $\begin{array}{l}\text { Bacillus subtilis } \\
\text { isolate B246 }\end{array}$ & $1 \times 10(9)$ & Avocadoes & Fruit spot \\
\hline 7495 & $\begin{array}{l}\text { Plant Health } \\
\text { Protection }\end{array}$ & Eco-77 & $\begin{array}{l}\text { Trichoderma } \\
\text { harzianum }\end{array}$ & $\begin{array}{l}2 \times 10 \mathrm{EG} \\
\text { spores/g }\end{array}$ & $\begin{array}{l}\text { Cucurbits } \\
\text { (cucumbers), } \\
\text { Grapes }\end{array}$ & $\begin{array}{l}\text { Botrytis, } \\
\text { eutypa }\end{array}$ \\
\hline 6938 & $\begin{array}{l}\text { Plant Health } \\
\text { Products }\end{array}$ & Eco-T & $\begin{array}{l}\text { Trichoderma } \\
\text { harzianum }\end{array}$ & $\begin{array}{l}5 \times 10(8) \\
\text { conidia/g }\end{array}$ & Various & $\begin{array}{l}\text { Root diseases, } \\
\text { Pythium root } \\
\text { rot, soil } \\
\text { pathogens }\end{array}$ \\
\hline 7456 & Dagutat Biolab & T-Gro & $\begin{array}{l}\text { Trichoderma } \\
\text { harzianum DB } 103\end{array}$ & $\begin{array}{l}1 \times 10(9) \\
\text { spores/g }\end{array}$ & Grapes (table) & $\begin{array}{l}\text { Botrytis, } \\
\text { powdery } \\
\text { mildew }\end{array}$ \\
\hline 7457 & Dagutat Biolab & Shelter & $\begin{array}{l}\text { Bacillus subtilis DB } \\
101\end{array}$ & $5 \times 10(7) \mathrm{CFU} / \mathrm{g}$ & Grapes (table) & $\begin{array}{l}\text { Botrytis, } \\
\text { powdery } \\
\text { mildew }\end{array}$ \\
\hline 7455 & Dagutat Biolab & Artemis & $\begin{array}{l}\text { Bacillus subtilis DB } \\
102\end{array}$ & $1 \times 10(8) \mathrm{CFU} / \mathrm{g}$ & Grapes (table) & $\begin{array}{l}\text { Botrytis, } \\
\text { powdery } \\
\text { mildew }\end{array}$ \\
\hline 6287 & $\begin{array}{l}\text { Makhteshim-Agan } \\
\text { SA (Pty) Ltd }\end{array}$ & $\begin{array}{l}\text { Trichodex } \\
\text { WP }\end{array}$ & $\begin{array}{l}\text { Trichoderma } \\
\text { harzianum strain T39 }\end{array}$ & $1 \times 10(9) \mathrm{CFU} / \mathrm{g}$ & Grapes (table) & Botrytis rot \\
\hline 7161 & $\begin{array}{l}\text { Biological Control } \\
\text { Products }\end{array}$ & Trichoplus & $\begin{array}{l}\text { Trichoderma } \\
\text { harzianum }\end{array}$ & $\begin{array}{l}2 \times 10(9) \\
\text { spores/g }\end{array}$ & Various & Root diseases \\
\hline 1380 & Stimuplant & $\begin{array}{l}\text { Crown Gall } \\
\text { Inoculant }\end{array}$ & $\begin{array}{l}\text { Agrobacterium } \\
\text { radiobacter }\end{array}$ & $5 \times 10^{\wedge} 8$ cells $/ g$ & $\begin{array}{l}\text { Apricots, } \\
\text { cherries, } \\
\text { peaches, roses, } \\
\text { chrysanthemums }\end{array}$ & Crown gall \\
\hline
\end{tabular}

representing $0.31 \%$ of the registered products in the country. These are listed in Table 5. Agricultural companies interviewed (Table 4), indicated that this figure is low, mainly due to hurdles in the registration process. In South Africa, registration of biocontrol products is time consuming and frustrating (Korsten, 2004). According to the DAFF's website, this process can take up to one year 
(www.nda.agric.za). Registration of Avogreen ${ }^{\circledR}$ in South Africa took three years to finalize, mainly due to a lack of proper regulatory guidelines for biopesticides (Korsten, 2004) at the time. This resulted in some biopesticide companies selling unregistered or untested products thereby harming the image of the industry in the long run. Guidelines for the registration of biopesticides (2010) have since been published by DAFF (http://www.nda.agric.za). This document describes the data requirements for biopesticide registration in South Africa and addresses the shortcomings and the needs of the industry. The situation for registering biological and chemical pesticides has however not changed and it still takes on average two years before a product is registered (Mr. Thilivhali personal communication).

\section{Conclusion}

Although farmers in South Africa experience unique challenges such as land reform, labour challenges and economic and infrastructural shortages, they are generally open for the idea of exploring biological control. Education level was found to be important in terms of technology adoption. Even though farmers don't have a clear understanding of the definition of biological control, they are willing to opt for this approach and don't generally blame past failures experienced when using biocontrol on poor product performance, but rather on factors such as the environment and a lack of perseverance from their side. Companies marketing biocontrol products in South Africa are faced with a severe lack of technical knowledge regarding handling and use of biocontrol products and are discouraged by the long registration process.

This study clearly indicated that education is one of the key influences on the successful adaptation of biological control programs in South Africa. Education programs at farmer study groups by qualified field technicians clearly influence farmer decision making. For Avogreen ${ }^{\circledR}$ biocontrol programs in South Africa a similar approach is suggested. This will include involvement of targeted (younger, farm managing level) farmers (Fig. 1) in study groups, together with qualified technicians (or scientists) with sufficient knowledge on biocontrol and the behavior of the antagonist under different conditions. This 
technician must also be capable to evaluate the performance of the biocontrol program and compare this in association with all benefits involved in the use of biocontrol against chemical disease control. It could be advantageous to target farmers in areas where study groups already exist and then extend the program to other areas, including rural areas or areas with new emerging farmers.

\section{Acknowledgements}

All farmers and agricultural companies involved with interviews. Mr. N Thilivhali, DAFF, Pretoria for advice and information regarding pesticide registration. ARC-Central Office (Ms MJ Smith), previously from the Biometry Unit, Pretoria provided statistical advice. All assistance is gratefully acknowledged.

\section{References}

Acka H, Sayili M and Onen H. 2006. Factors affecting decision-making of farmers in weed management (case study of Tokat, Turkey). Journal of Plant Diseases and Protection, 709 - 715.

Agwu A E, Ekwueme J N and Anyanwu A C. 2008. Adoption of improved agricultural technologies disseminated via radio farmer programme by farmers in Enugu State, Nigeria. African Journal of Biotechnology, 7 (9): 1277 1286.

Andrews K L, Bentley J W and Cave R D. 1992. Enhancing biological control's contributions to integrated pest management through appropriate levels of farmer participation. The Florida Entomologist, 75 (4): 429 - 439.

Bagheri, A. 2010. Potato farmers' perceptions of sustainable agriculture: the case of Ardabil province of Iran. Procedia Social and Behavioral Sciences, 5: 19777 - 1981. 
Bailey, K L, Boyetchko, S M and Längle, T. 2010. Social and economic drivers shaping the future of biological control: A Canadian perspective on the factors affecting the development and use of microbial biopesticides. Biological Control, 55: $221-229$

Burton R J F. 2006. An alternative to farmer age as an indicator of life-cycle stage: the case for a farm family age index. Journal of Rural Studies, 22 (4): 485 - 492.

Darvas J M, Kotze J M and Wehner F C. 1987. Pathogenicity of fungi causing pre- and postharvest diseases of avocado fruit. Phytophlactica, 19: $489-493$.

Everett K R, Owen S G and Cutting J G M. 2005. Testing efficacy of fungicides against postharvest pathogens of avocado (Persea americana CV. Hass). New Zealand Plant Protection, 58: 89 - 95.

Fraser A. 2008. White farmers' dealings with land reform in South Africa: Evidince from northern Limpopo province. Tijdschrift voor Economische en Sociale Geografie, 99 (1): 24 - 36.

Fravel D R. 2005. Commercialization and implementation of biocontrol. Annual Review of Phytopathology, 43: 337 359.

Groenewalt J A. 2003. Conditions for successful land reform in Africa. Pre-IAAE Symposium, Bloemfontein, South Africa, viewed 31 October 2011 Available on the internet http://ageconsearch.umn.edu/bitstream/28068/1/cp03gr01.pdf.

Harman G E. 1998. Biocontrol - Why a different approach is needed. Alternative paradigms for commercializing biological control workshop. Experiment station committee on policy - Biological control working group (ESCOP-WGBC) and Rutgers University, New Brunswick, New Jersey, viewed 31 October 2011. Available on the internet http://www.rci.rutgers.edu/ insects/harsum.htm.

Irtwange S V. 2006. Application of biological control agents in pre- and post-harvest operations. Agricultural engineering International: the CIGR Ejournal. Invited Overview, 3: 1 - 12, viewed 31 October 2011. Available from the internet http://ecommons.cornell.edu/handle/1813/10564. 
Jatsum A R, Franz J M, Deacon J W, Payne C C, Lewis T, Paterson R R M, Waage J K and van Emden H F. 1988. Commercial application of biological control: status and prospects [and discussion]. Philosophical Transactions of the Royal Society of London, Series B, Biological Sciences, 318 (1189): 357 - 373.

Korsten L. 2004. Biological control in Africa: can it provide a sustainable solution for control of fruit diseases? South African Journal of Botany, 70 (1): 128 - 139.

Korsten L, de Villiers E E, Duvenhage J A and Kotze J M. 1994. Control of avocado pre-harvest diseases with Bacillus subtilis and fungicide sprays. South African Avocado Growers' Association Yearbook, 17: 32 - 34.

Korsten L, de Villiers E E, Wehner F C and Kotze J M. 1997. Field sprays with Bacillus subtilis and fungicides for control of pre-harvest fruit diseases of avocado in South Africa. Plant Disease, 81 (5): 455 -459.

Lobley M, Butler A and Reed M. 2009. The contribution of organic farming to rural development: An exploration of the socio-economic linkages of organic and non-organic farms in England. Land Use Policy, 26: 723 - 735.

Moser R, Kpertot I, Elad Y and Raffaelli R. 2008. Farmers' attitudes towards the use of biocontrol agents in IPM strawberry production in three countries. Biological control, 47: $125-132$.

Mzoughi, N. 2011. Farmers adoption of integrated crop protection and organic farming: Do moral and social concerns matter? Ecological Economics, 70: 1536 - 1545.

Norton G A. 1976. Analysis of decision making in crop protection. Agro-Ecosystems, 3: 27 - 44.

Siegel S. 1956. Non-parametric statistics for the behavioural sciences. New York: McGraw-Hill Book Co. Inc.

Snedecor G W and Cochran W G. 1980. Statistical Methods, Seventh Edition, Iowa State University Press: Iowa State.

Towsen E, van Wyngaardt S, Verschoor J A and Korsten L. 1995. The importance of monitoring antagonist survival for efficient biocontrol. South African Avocado Growers' Association Yearbook, 18: 121 - 130. 
Valentin R J. 2002. Economics of marketing and technical support in the commercial biological control industry. First International Symposium on Biological Control of Arthropods. p. 151 - 153, viewed 20 October 2009. Available on the internet www.bugwood.org/arthropod.

Van der Waals J E, Korsten L and Denner F D N. 2003. Early blight in South Africa: Knowledge, attitudes and control practices of potato growers. Potato Research, 46 (1-2): 27 - 37.

Ying, X. and Min, L. 2011. Research on farmer's production willingness of safe agricultural products and its influence factors: An empirical analysis in China. Energy Procedia, 5: 53-58. 